\title{
The Effect of Environmental Factors (Temperatures \& Humidity) on the Solar Cell Performance / Matlab Model
}

\author{
Zina Abd Alameer Al Shadidi \\ Physics Department, University of Aden, Faculty of Education/Sabr, Aden, Yemen \\ Email address: \\ zabaqer@yahoo.com
}

\section{To cite this article:}

Zina Abd Alameer Al Shadidi. The Effect of Environmental Factors (Temperatures \& Humidity) on the Solar Cell Performance / Matlab Model. International Journal of Applied Mathematics and Theoretical Physics. Vol. 6, No. 4, 2020, pp. 61-67.

doi: $10.11648 / j$. .jamtp.20200604.12

Received: November 7, 2020; Accepted: November 27, 2020; Published: December 4, 2020

\begin{abstract}
This paper provides an accurate modeling method for the photovoltaic panel using Matlab software. The mathematical model discusses the effect of the environmental factors on PV panels. The model based on specifications given on the manufacturer's plate, a previous Simulink model was developed using Matlab code, to include the effect of humidity on the solar cell performance and efficiency. In the previous work on P-V characteristics, the temperature effect is discussed adequately, without mention the humidity side effects. In this paper, the effect of humidity on the fill factor and efficiency of solar cells is discussed. The conclusions come with many side effects of the humidity on the solar cell, which is the sediments trapped by water molecules, and energy loss due to the reflections of light from the condensed water surface. In addition to the heat carried by moister. The effect of this kind of heat has been studied through calculating the enthalpy of the moist air, and feel like temperature). According to this model and in Silicon solar cell, the lost energy due to reflection was equal to $\left(\mathrm{G}_{\mathrm{ave}}=842.0175 \mathrm{w} / \mathrm{m}^{2}\right)$ on average. Due to this loss, solar cell current and voltage will be different. All these effects lead to a decrease in the fill factor and the efficiency of the solar cell, because of a reduction in the absorbing energy.
\end{abstract}

Keywords: Solar Cell Efficiency, Matlab Code, Air Humidity

\section{Introduction}

The study of the behavior of solar cells with wide range of temperature is notable, as in earth wide range of temperature. And with the growing need for the clean cheap energy sources. Solar cells are the most clean source used, because of its material cheap price and the ease of use.

The operation of solar cells degrades with the growing up temperature. The performance and the efficiency of the solar cell depends on the cells material, short circuit current, open circuit voltage, fill factor, the weather including the ambient temperature, and humidity. [1-8].

Photovoltaic array systems are familiar and wide utilize in electric power generation, the only condition to its operation is sun exposure.

With different weather conditions like temperature and humidity, the solar cell performance, and the cell efficiency will be different. Therefore a slandered mathematical model for a PV array is very important. Many authors write about the temperature dependence but not the combination of the other main weather factors like humidity.

It is necessary to provide a theoretical measure of daily natural effects that accompany weather changes. The theoretical basis, is the root for construction for the concepts we are study. The theoretical results is very important to reduce and save time, money, and effort. Many researches deal with the effect of temperature.

Sabrina Benabbas, Zahir Rouabah, Hocine Heriche and Nacer-Eddine Chelali [9], improve the performance of the CIGS solar cell by inserting the $\mathrm{SnS}$ layer between the absorber layer CIGS and the Mo. The performance of CIGS solar cells was improved when the absorber layer thickness was increased. Saad Motahhir, Abdelilah Chalh, Abdelaziz El Ghzizal, Souad Sebti and Aziz Derouich [10], focuses on a Proteus Spice model of the photovoltaic Panel. This model is based on a mathematical equation which is got from the equivalent circuit of the photovoltaic Panel. Huan-Liang Tsai, Ci-Siang Tu, and Yi-Jie Su, Member, IAENG [11], presents the implementation of a generalized photovoltaic model using Matlab/Simulink, which can be representative of PV 
cell, and array for easy use on simulation platform.

N. Liman, A. Belghachi [12], studied the efficiency increases about 22.2 For CdTe concentrator solar cell, and has reached 25\% in CIGS concentrator solar cell. Gunjan Varshney1, D. S. Chauhan2, M. P. Dave [13], modeled of solar array with the use of Simscape library, tom study the Maximum power (maximum power point tracking (MPPT)), results are shown in the form of various characteristics of solar array.

Priyanka Singh n, N. M. Ravindra [14], studied The temperature dependence of performance parameters, Voc, Jsc, FF of Ge, Si, GaAs, InP, CdTe and, CdS solar cells in the temperature range273-523K. Habbati Bellia, Ramdani Youcef, Moulay Fatima [15], modele the effect of irradiance and temperature on the parameters of the PV module. Shivananda Pukhrem [16], simulate a model for PV cell for estimating the IV characteristic curves of photovoltaic panel with respect to changes on environmental parameters (temperature and irradiance) and cell parameters (parasitic resistance and ideality factor).

\section{Simulation and PV Model}

With very primitive circuit diagram the solar cell regarded as a current source in parallel with a diode, as shown in figure 1. Nowadays the users in the world look at solar cells as a very important source of electric current in the present of the sun light it will produce the photocurrent $\left(I_{p h}\right)$. and they need this current in the dark, therefore the diode as a $p-n$ junction, will represent a current source when the solar cell does not produce the current (in dark). When this cell connect to a resistance, it will generate $I_{d}$.

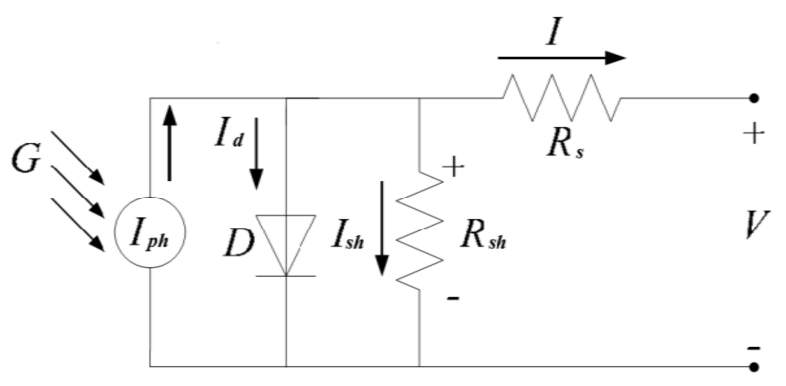

Figure 1. Simplified model for P-V circuit.

$$
V_{o c}=\frac{K T_{o p}}{q} \ln \frac{I_{p h}}{I_{S}}
$$

$\mathrm{K}$ represents Boltzman constant, $\mathrm{T}_{\mathrm{op}}$ is the operation temperature, and $\mathrm{q}$ is the electron charge.

$V_{o c}$ is the open circuit voltage, $I_{p h}$ represents the photocurrent, and $I_{S}=$ diode reverse saturation current.

$$
I_{d}=\left[e^{\left.\frac{V+I R_{S}}{\left(B \frac{K T_{o p}}{q} n N_{S}\right)}\right)}-1\right] I_{S} N_{p}
$$

$\mathrm{I}_{\mathrm{d}}$ represents the diode current, $\mathrm{v}$ is the circuit voltage $\mathrm{I}$ is the circuit current $R_{S}$ series resistance of equivalent PV cell B diode ideality factor $\mathrm{n}=$ number of cells in PV panel. $N_{s}$ number of series panel $N_{p}$ number of parallel panel

$$
I_{s}=I_{r s}\left(\frac{T_{o p}}{T_{r e f}}\right)^{3} e^{\left[\frac{q E g}{n k}\left(\frac{1}{T_{o p}}-\frac{1}{T_{r e f}}\right)\right]}
$$

$I_{r s}=$ Diode reversed saturation current_ $T_{o p}$ operating temperature $T_{\text {ref }}$ cell temperature. $E_{g}$ energy gap of cell material.

$$
I_{r s}=\frac{I_{s c}}{\left[e^{\frac{V_{o c} q}{K c T o p^{n}}}-1\right]}
$$

$I_{S C}$ the shunt current

$$
I_{s h}=\frac{V+I R_{S}}{R_{p}}
$$

$R_{p}$ is Parallel Resistance of Equivalent PV cell

$$
I_{p h}=A\left[I_{s c}+K_{I}\left(T_{o p}-T_{r e f}\right)\right.
$$

A is the solar irradiance ratio.

$$
I=I_{p h} N_{p}-I_{d}-I_{s h}
$$

I is the total current, $I_{d}$ is the diode current.

The PV model using Simulink (Matlab) describe the output characteristics affected by the cell temperature. According to the above equations (1-7), a simulation results expressed in figures $1 \& 2$. With the following information.

The temperature range in figure 2 is between room temperature $\left(30^{\circ} \mathrm{C}\right)$ and a very high temperature for operating the solar cell system under hard circumstances $\left(80^{\circ} \mathrm{C}\right)$. from this figure it is obvious that increasing temperature cases increase the power related to the increasing the operating system voltage.

For a wide range of temperature, the resultant data collected and arranged in the following tables:

Table 1. Represents the variables used in P-V simulation.

\begin{tabular}{ll}
\hline $\mathrm{K}=1.38065 \mathrm{e}-23$ & Boltzman Constant \\
$\mathrm{q}=1.602 \mathrm{e}-19$ & Electron's Charge \\
$I_{s c n}=3.8$ & Short Circuit Current \\
$V_{\text {ocn }}=21.1$ & Open Circuit Voltage \\
$K_{v}=-0.073$ & Temperature Voltage Constant \\
$\mathrm{Ki}=0.0032$ & Temperature Current Constant \\
$\mathrm{Ns}=36$ & Number of Series Connected Cells \\
$N_{p}=6$ & Number of parallel Connected Cells \\
$\mathrm{T}=30+273$ & Temperature in STC \\
$\mathrm{An}=1000$ & Irradiance at STC \\
$E g=1.2$ & \%Band Gap of silicon at Temperature of STC \\
$R_{s}=0.221$ & condition \\
$R_{p}=415.405$ & Series Resistance of Equivalent PV cell \\
$\mathrm{A}=0.0639 \mathrm{~m}^{2}$ & \%rearallel Resistance of Equivalent PV cell \\
\hline
\end{tabular}




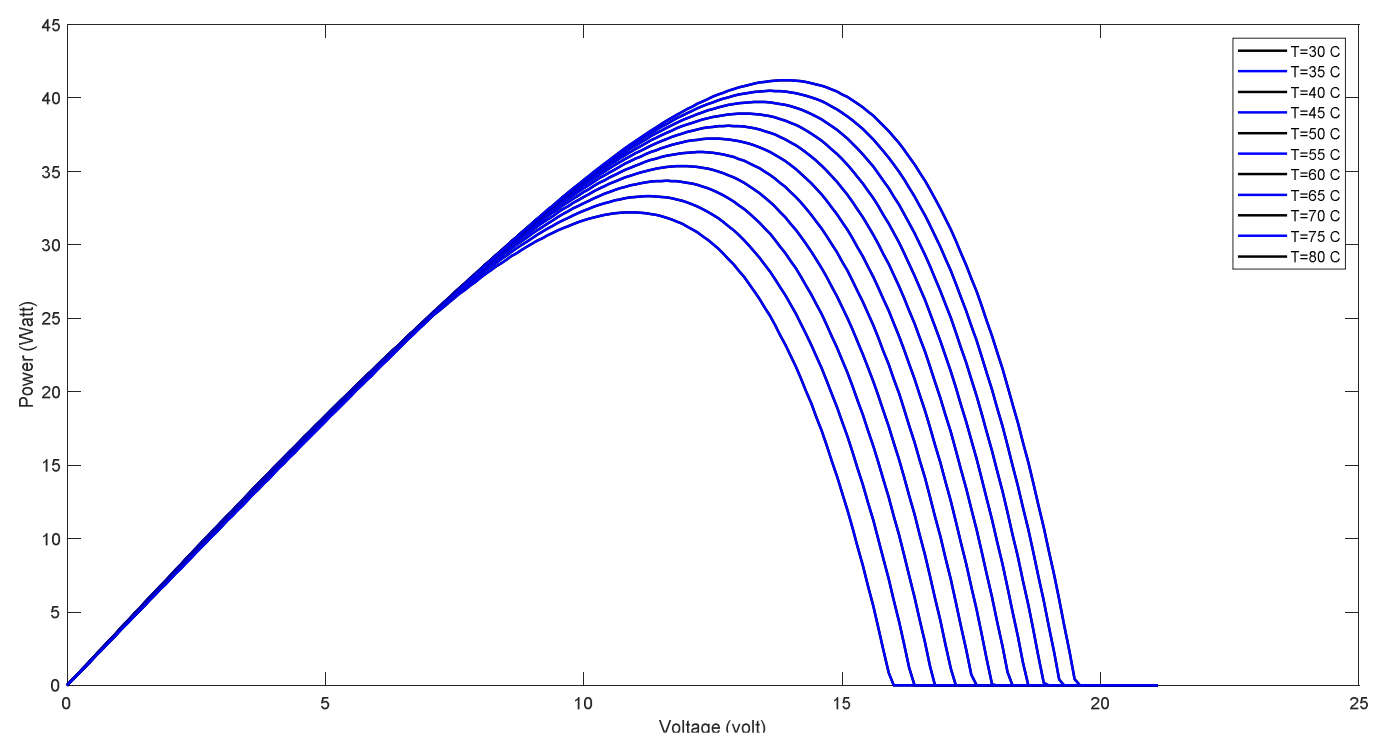

Figure 2. Shows the power as a function of solar cell voltage at different temperature.

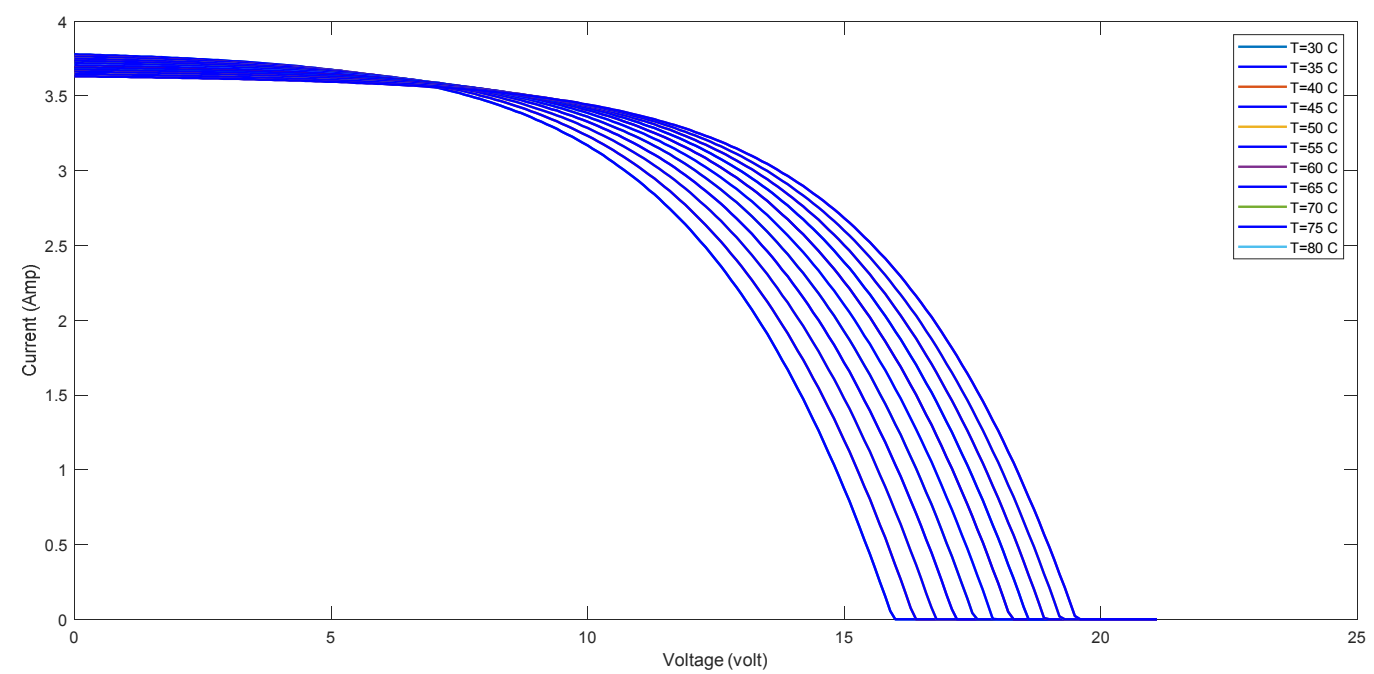

Figure 3. Represents the current dependance on the cell voltage.

Table 2. Represents the effect of ambient temperature on maximum power point, voltage at maximum power point, current at maximum power point.

\begin{tabular}{llll}
\hline $\mathbf{T}^{\circ} \mathbf{C}$ & $\begin{array}{l}\text { V at } \mathbf{m p p} \\
\left(\boldsymbol{V}_{\boldsymbol{m a x}}\right)(\mathbf{V})\end{array}$ & $\begin{array}{l}\mathbf{I} \text { at } \mathbf{m p p} \\
\left(\boldsymbol{I}_{\boldsymbol{m a x}}\right)(\mathbf{A})\end{array}$ & $\boldsymbol{P}_{\boldsymbol{m a x}}=\boldsymbol{V}_{\boldsymbol{m} \boldsymbol{m} \boldsymbol{p}} \boldsymbol{I}_{\boldsymbol{m} \boldsymbol{m} \boldsymbol{p}}$ \\
\hline 80 & 10.9 & 2.956 & 32.2204 \\
75 & 11.3 & 2.958 & 33.4254 \\
70 & 11.6 & 2.962 & 34.3592 \\
65 & 11.9 & 2.971 & 35.3549 \\
60 & 12.2 & 2.974 & 36.2828 \\
55 & 12.5 & 2.976 & 37.2000 \\
50 & 12.8 & 2.977 & 38.1056 \\
45 & 13.2 & 2.979 & 39.3228 \\
40 & 13.4 & 2.985 & 39.9990 \\
35 & 13.7 & 2.990 & 40.9630 \\
30 & 13.9 & 2.994 & 41.6166 \\
\hline
\end{tabular}

Fill Factor $=\left(V_{m m p} * I_{m m p} / V_{o c} * I_{s c}\right)$

Efficiency $=\left(P_{\text {max }} / P_{\text {in }}\right)=\left(V_{\text {mmp }} * I_{m m p} * F F / a * G\right)$

$$
\mathrm{a}=0.0639, \mathrm{G}=1000 \mathrm{~W} / \mathrm{m}^{2}
$$

Table 3. Represents the effect of ambient temperature on the open circuit temperature.

\begin{tabular}{lllll}
\hline $\mathbf{T}$ & $\boldsymbol{V}_{\boldsymbol{o c}}$ & $\boldsymbol{I}_{\boldsymbol{s c}}$ & Efficiency & Fill Factor \\
\hline 80 & 16.2 & 3.777 & 26.5500 & 0.5266 \\
75 & 16.6 & 3.763 & 27.99050 & 0.5351 \\
70 & 17.2 & 3.739 & 28.7277 & 0.5343 \\
65 & 17.6 & 3.734 & 29.7654 & 0.5380 \\
60 & 18.1 & 3.72 & 30.5970 & 0.5398 \\
55 & 18.6 & 3.706 & 31.4171 & 0.5397 \\
50 & 19 & 3.691 & 32.4025 & 0.5434 \\
45 & 19.4 & 3.676 & 33.9321 & 0.5514 \\
40 & 19.9 & 3.662 & 34.3579 & 0.5489 \\
35 & 20.3 & 3.647 & 35.4692 & 0.5533 \\
30 & 20.7 & 3.632 & 36.0509 & 0.5535 \\
\hline
\end{tabular}

For a wide range of temperature, the resultant (MPP) maximum power point, the current (at maximum power point) $\left(I_{\max }\right)$, and the voltage at the maximum power point $\left(V_{\max }\right)$. Were calculated and listed in the above tables. On the other hand the open circuit voltage $\left(V_{o c}\right)$ were calculated, it is found to be changed with the changing of the ambient temperature $(\mathrm{T})$. 
All the above factors are increased with the ambient temperature. These results agreed with the results of Adil Salman [11], and the results of Huan-Liang [17].

\section{Humidity Effect}

The side effects of the moister will be studied through the following points:

\subsection{Enthalpy of Moist Air and Feel Like Temperature}

The same model approved trough calculating the effect of humidity and its holding heat, on the solar cells performance.

In order to have a mathematical description for the heat holded by the water vapor, the direct moisture effect on the efficiency of solar cells will be studied. Some hypotheses will be provided first.

1 all heat carried by the water vapor contact the solar cell is transmitted to it.

2 The size of the steam contacting the cell will be proportional to the cell area.

3 The thermal transition process takes place under constant pressure

It makes sense to assume that the total enthalpy $\mathrm{H}$ of the moist air equals to the enthalpy of dry air plus the enthalpy of the evaporated water within the air:

$$
\boldsymbol{d} H=d H_{a}+x d H_{w}
$$

where

$H=$ represents the specific enthalpy of humid air, $H_{a}=$ the specific enthalpy of air, $x=$ humidity ratio, $H_{w}=$ specific enthalpy of water vapor

Assuming constant pressure conditions the specific enthalpy of dry air can be expressed as:

$$
d H_{a}=C_{p a} d T
$$

Where

$C_{p a}=$ specific heat of air at constant pressure, $T=$ air temperature

the water vapor specific enthalpy at constant pressure can be expressed as:

$$
d H_{w}=C_{p w} d T+d H_{w e}
$$

where

$C_{p w}=$ specific heat of water vapor at constant pressure $\left(\mathrm{kJ} / \mathrm{kg}^{\circ} \mathrm{C}\right), \mathrm{T}=$ vapor temperature $\left({ }^{\circ} \mathrm{C}\right)$

$H_{w e}=$ water evaporation heat at $0^{\circ} \mathrm{C}(\mathrm{kJ} / \mathrm{kg})$

$C_{p w}$ specific heat (water at $0^{\circ} \mathrm{C}$ )

Using equations (10) and (11), equation (9) can be modified to

$$
d H=C_{p a} d T+x\left[C_{p w} d T+d H_{p w}\right]
$$

where, $x_{s}$ represents the humidity ratio at saturation

$$
\begin{gathered}
d \mathrm{Q}=\mathrm{m} C_{p} \Delta T \\
\mathrm{du}=\mathrm{dQ}-\mathrm{PdV}-\mathrm{d} \dot{w}
\end{gathered}
$$

where $d w$ represents the isotropic work which is equal to zero in this case.

$$
\begin{gathered}
d H=d U+d(P V) \\
d H=d Q+V d p+P d V-p d V-d \dot{w} \\
d \dot{w}<0, d P=0 \\
d H=d Q=m C_{p} d T \\
d H=C_{p a} d T+x\left(C_{p w} d T+d H_{w e}\right)=m C_{p} d T \\
C_{p a} d T+x\left(C_{p w} d T+d H_{w e}\right)=m C_{p} d T \\
C_{p a}\left(T-T_{0}\right)+x\left(C_{p w}\left(T-T_{0}+d H_{w e}\right)=m C_{p}\left(T-T_{0}\right)\right.
\end{gathered}
$$

Let $T_{0}=25 \mathrm{C}$

$$
\begin{aligned}
& d H_{w e}=2501(\mathrm{~kJ} / \mathrm{kg}) \\
& c_{w}=4.19\left(\mathrm{~kJ} / \mathrm{kg}^{\circ} \mathrm{C}\right) \\
& C_{p w}=1.84\left(\mathrm{~kJ} / \mathrm{kg}^{\circ} \mathrm{C}\right)
\end{aligned}
$$

For air temperature between $-100^{\circ} \mathrm{C}$ and $100^{\circ} \mathrm{C}$ :

$$
\begin{gathered}
C_{p a}=1.006\left(\frac{K J}{K g} C\right) \\
C_{p a}\left(T-T_{0}\right)+x\left(C_{p w}\left(T-T_{0}\right)+d H_{w e}\right)-m C_{p}\left(T-T_{0}\right)=0
\end{gathered}
$$

Substituting all the above constants, regarding that $T_{0}=25 c^{o}$, the temperature with respect to humidity ratio will represent as follows:

$$
T=\frac{2501 \times C_{p a}}{C_{p a} x C_{p w}-m C_{p}}+T_{0}
$$

From the above table, at $25 C^{o}, x_{s}=0.019826$.

$$
A H=\frac{m_{\mathrm{H}_{2} \mathrm{O}}}{V}
$$

Where $\mathrm{AH}=$ absolute Humidity, $\mathrm{V}=$ humid air volume, $m_{\mathrm{H}_{2} \mathrm{O}=}$ water vapor mass

Substituting (23) in (24), and for $V=1 \mathrm{~m}^{3}$.

$$
\begin{gathered}
C p=1.005+1.82 \mathrm{AH} \\
T=\frac{2501 \times C_{p a}}{C_{p a} \times C_{p w}-m(1.005+1.82 \mathrm{~m})}+T_{0}
\end{gathered}
$$

where $1.005 \mathrm{~kJ} / \mathrm{kg}^{\circ} \mathrm{C}$ is the heat capacity of dry air, 1.82 $\mathrm{kJ} / \mathrm{kg}^{\circ} \mathrm{C}$ the heat capacity of water vapor, and $\mathrm{H}$ is the absolute humidity in $\mathrm{kg}$ water vapor per $\mathrm{kg}$ dry air in the mixture. So the specific heat capacity of humid air is greater than dry air and humid air will take more energy to heat by a given amount.

From this figure it is clear that increasing the absolute humidity with will increase the feel like temperature. As shown in figure 5.

From figure 5 we can detect the effect of the stored heat in the water vapor on the solar cell through the effect of temperature rising. 


\subsection{Water Reflectance}

The water produced by moisture as a layer covering the surface of the cell. This water may reflect a part of light away from the cell. the reflection from the water surface can be calculated by using Fresnel equation. A real water surface may not be randomly distributed. As a mathematical approximation, the water surface assumed to be wavy.

Figure 4 Describes equation (26), which represents the effect of absolute humidity on the ambient temperature, which has an effective role in changing the resultant performance of the solar cell.

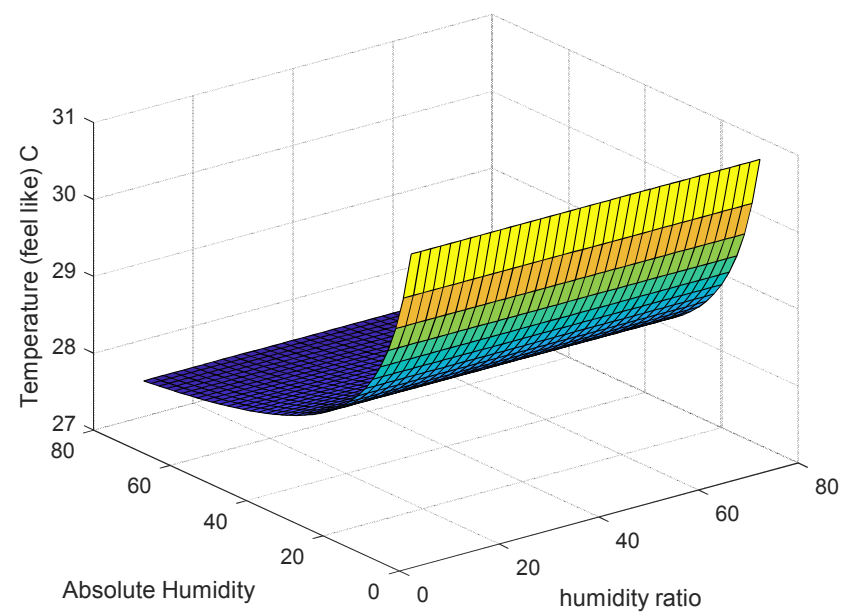

Figure 4. Represents the effect of absolute humidity on the ambient temperature,.

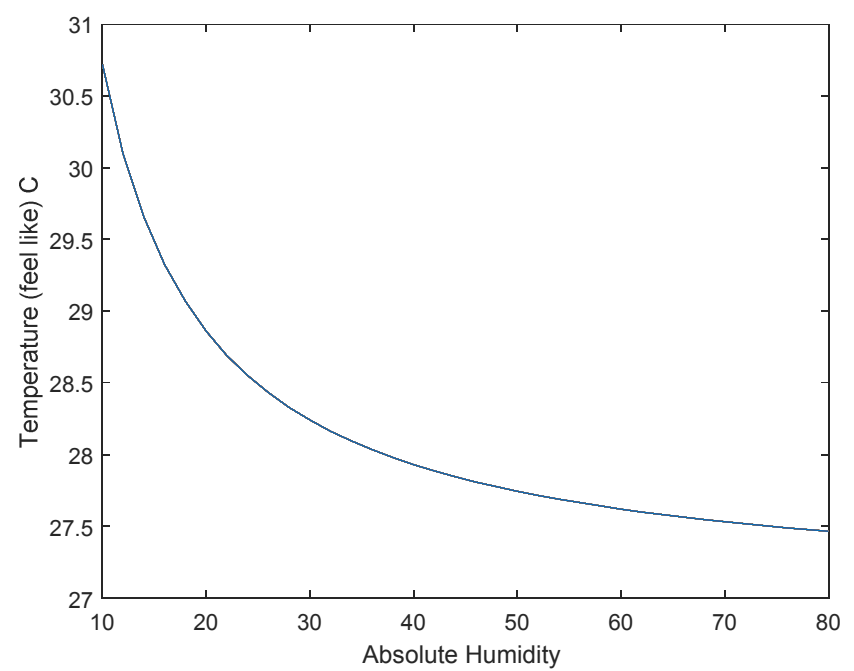

Figure 5. Represent the feel like temperature dependence on the absolute humidity.
The reflectance for the s- polarized light

$$
R_{S}=\left|\frac{n_{1} \cos \theta_{i}-n_{2} \cos \theta_{t}}{n_{1} \cos \theta_{i}+n_{2} \cos \theta_{t}}\right|^{2}=\left|\frac{n_{1} \cos \theta_{i}-n_{2} \sqrt{1-\left(\frac{n_{1}}{n_{2}} \sin \theta_{i}\right)^{2}}}{n_{1} \cos \theta_{i}+n_{2} \sqrt{1-\left(\frac{n_{1}}{n_{2}} \sin \theta_{i}\right)^{2}}}\right|^{2}
$$

While The reflectance for the p-polarized light.

$$
R_{p}=\left|\frac{n_{1} \cos \theta_{t}-n_{2} \cos \theta_{i}}{n_{1} \cos \theta_{t}+n_{2} \cos \theta_{i}}\right|^{2}=\left|\frac{n_{1} \sqrt{1-\left(\frac{n_{1}}{n_{2}} \sin \theta_{i}\right)^{2}}-n_{2} \cos \theta_{i}}{n_{1} \sqrt{1-\left(\frac{n_{1}}{n_{2}} \sin \theta_{i}\right)^{2}}+n_{2} \cos \theta_{i}}\right|^{2}
$$

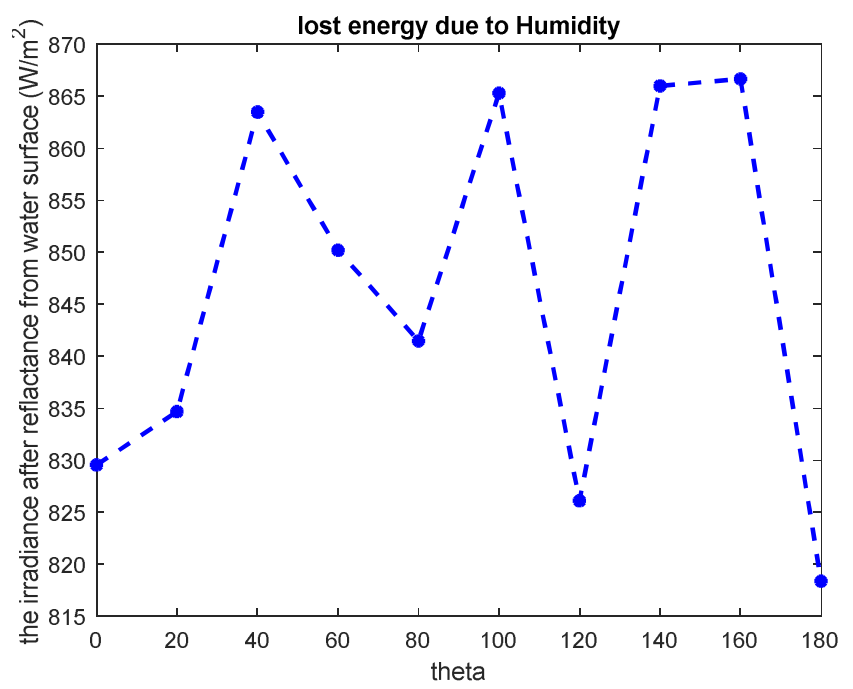

Figure 6. Represents the irradiance distribution with the angle of light incident.

The irradiance power per unit area equal to the portion of the non-reflected incident power.

$$
T_{e f f}=1-R_{e f f}
$$

According to the polarization kind, the irradiance must be calculated. Although in these kind of calculations, the sun light (for unpolarized light) must be considered. an equal amount of power existed in the two kinds of polarizations, therefore the effective reflectivity of the material equal to the average of $R_{s}$ and $R_{p}$ :

$$
\begin{aligned}
T & =\frac{\text { Transmitted energy }}{\text { Total energy }} \\
T_{\text {eff }} & =1-\frac{1}{2}\left(R_{S}+R_{p}\right)
\end{aligned}
$$




$$
\begin{gathered}
\frac{A}{A_{0}}=1-\frac{1}{2}\left(\left|\frac{n_{1} \cos \theta_{i}-n_{2} \sqrt{1-\left(\frac{n_{1}}{n_{2}} \sin \theta_{i}\right)^{2}}}{n_{1} \cos \theta_{i}+n_{2} \sqrt{1-\left(\frac{n_{1}}{n_{2}} \sin \theta_{i}\right)^{2}}}\right|^{2}+\left|\frac{n_{1} \sqrt{1-\left(\frac{n_{1}}{n_{2}} \sin \theta_{i}\right)^{2}}-n_{2} \cos \theta_{i}}{n_{1} \sqrt{1-\left(\frac{n_{1}}{n_{2}} \sin \theta_{i}\right)^{2}}+n_{2} \cos \theta_{i}}\right|^{2}\right. \\
A=A_{0}-\frac{1}{2} A_{o}\left(\left|\frac{n_{1} \cos \theta_{i}-n_{2} \sqrt{1-\left(\frac{n_{1}}{n_{2}} \sin \theta_{i}\right)^{2}}}{n_{1} \cos \theta_{i}+n_{2} \sqrt{1-\left(\frac{n_{1}}{n_{2}} \sin \theta_{i}\right)^{2}}}\right|+\left|\frac{n_{1} \sqrt{1-\left(\frac{n_{1}}{n_{2}} \sin \theta_{i}\right)^{2}}-n_{2} \cos \theta_{i}}{n_{1} \sqrt{1-\left(\frac{n_{1}}{n_{2}} \sin \theta_{i}\right)^{2}}+n_{2} \cos \theta_{i}}\right|^{2}\right)
\end{gathered}
$$

According to equation (35) the solar irradiance will be reduced because of the reflectance from the water surface. Reducing A affect the PV cell performance through reducing the resultant voltage and current.

According to this model and in Silicon solar cell, the maximum lost energy due to reflection was equal to $\left(817.3668 \mathrm{w} / \mathrm{m}^{2}\right)$. The minimum lost energy due to reflection from the water surface was $\left(866.6682 \mathrm{w} / \mathrm{m}^{2}\right)$. This variation in the lost energy amount due to the variation of the light incident angle.

The average amount of the lost energy will be equal to $\left(\mathrm{G}_{\text {ave }}=842.0175 \mathrm{w} / \mathrm{m}^{2}\right)$.

Due to this loss many factors will be different such as current and voltage, and according to that the efficiency of the solar cell. The above result agree with the results of Manoj Kumar Panjwani, Dr. Ghous Bukshsh Narejo1 [18], and Abdou Latif Bonkaney, Saidou Madougou, Rabani Adamou [19].

\section{Conclusions}

From the simulation results represented by the PV solar cell model, equation (26) and equation (38), the following results was concluded.

Moister affects the solar cell performance negatively.

Humidity increases the heat supplied on the cell.

Humidity contributes to the destruction of the cell by forming hard layers of salts and dust. Sediments that are trapped by water molecules on the surface of the cell.

The condensed water on the cell surface reflects part of the light away from the cell surface, therefore a decrease in the amount of solar energy that benefit the cell is observed.

The reflected energy described by equation (38). and according to this equation, the reflected energy depends on the reflecting index of water, the reflecting index of the cell material, and the angle of incident light. In addition to the previous parameters the polarization kind of the incident light must be considered. In the case of non-polarized solar light the two kinds of polarization must be considered to calculate the full light energy.

According to this model and in Silicon solar cell, the maximum lost energy due to reflection was equal to $\left(817.3668 \mathrm{w} / \mathrm{m}^{2}\right)$. The minimum lost energy due to reflection from the water surface was $\left(866.6682 \mathrm{w} / \mathrm{m}^{2}\right)$. The variation in the lost energy amount was due to the variation of the light incident angle.

The average amount of the lost energy will be equal to
$\left(\mathrm{G}_{\text {ave. }}=842.0175 \mathrm{w} / \mathrm{m}^{2}\right)$.

Due to this loss many factors will be different such as current and voltage, and according to that the efficiency of the solar cell.

\section{References}

[1] S. M. Sze, "Physics of semiconductor devices", John Wiley \& Sons, New York, 1981, p. 264 (Chapter 14).

[2] G. Landis, R. Rafaelle, D. Merritt, 2004, "High temperature solar cell development", 19th European Photo voltaic Science and Engineering Conference, Paris, France, June 7-11.

[3] J. J. Wysocki, P. Rappaport, 1960, "Effect of temperature on photo voltaic solar energy conversion", Journal of Applied Physics 31, 571-578.

[4] J. C. C. Fan, 1986, "Theoretical temperature dependence of solar cell parameters", Solar Cells 17 309-315.

[5] P. Singh, S. N. Singh, M. Lal, M. Husain, 2008, "Temperature dependence of I-V characteristics and performance parameters of silicon solar cell", Solar Energy Materials and Solar Cells 92, 1611-1616.

[6] D. J. Friedman, 1996, "Modeling of tandem cell temperature coefficients", in: 25th IEEE Photovoltaic Specialists Conference, Washington DC, IEEE, New York, pp. 89-92.

[7] M. A. Contreras, T. Nakada, A. O. Pudov, R. Sites, 2003, " $\mathrm{ZnO} / \mathrm{ZnS}(\mathrm{O}, \mathrm{OH}) / \mathrm{Cu}(\mathrm{In}, \mathrm{Ga}) \mathrm{Se}_{2} /$ Mo solar cell with $18.6 \%$ efficiency", in: Proceedings of the Third World Conference of Photovoltaic Energy Conversion, pp. 570-573.

[8] M. J. Jeng, Yu. L. Lee, L. B. Chang, 2009, "Temperature dependences of $\operatorname{lnxGa} 1$ xN multiple quantum well solar cells", Journal of Physics D: Applied Physics, vol. 42, Iss. 10. pp. 6.

[9] Sabrina Benabbas, Zahir Rouabah, Hocine Heriche, and Nacer-Eddine Chelali, 2016, "A numerical study of high efficiency ultra-thin CdS/CIGS solar cells", African Journal of Science, Technology, Innovation and Development, pp. 13.

[10] Saad Motahhir, Abdelilah Chalh, Abdelaziz El Ghzizal, Souad Sebti and Aziz Derouich, 2017, "Modeling of photovoltaic panel by using proteus", Journal of Engineering Science and Technology Review 10 (2), 8-13.

[11] Huan-Liang Tsai, Ci-Siang Tu, and Yi-Jie Su, Member, $I A E N G$, 2008, "Development of generalized photovoltaic model using MATLAB/SIMULINK", Proceedings of the World Congress on Engineering and Computer Science, WCECS October 22 - 24, San Francisco, USA. 
[12] N. LIMAM, A. BELGHACHI, 2017, "Analysis of CIGS and CdTe solar cell concentrators", Journal of Ovonic Research Vol. 13, No. 3, May - June, p. 129-134.

[13] Gunjan Varshney1, D. S. Chauhan2, M. P. Dave, 2014, "Simscape based modelling \& simulation of MPPT controller for PV sSystems', IOSR Journal of Electrical and Electronics Engineering (IOSR-JEEE) Volume 9, Issue 6 Ver. 1, PP 41-46 www.Iosrjournals.Org.

[14] "Priyanka Singh n, N. M. Ravindra, 2012, "Temperature dependence of solar cell performance - an analysis", Solar Energy Materials \& Solar Cells, Elsvier, 101, pp. 36-45.

[15] Habbati Bellia a, *, Ramdani Youcef b, Moulay Fatima, 2014, "A detailed modeling of photovoltaic module", NRIAG Journal of Astronomy and Geophysics, vol 3, pp. 53-61, Taylor \& Frances.

[16] Shivananda Pukhrem, "A photovoltaic panel model in
Matlab/Simulink",

https://www.researchgate.net/publication/255721161.

[17] Adil Salman1, Arthur Williams2, Hanya Amjad3, M. Kamran Liaqat Bhatti3, M. Saad, 2015, "Simplified modeling of a PV Panel by using PSIM and its comparison with Laboratory Test Results", Conference Paper · October, DOI: 10. 1109/GHTC. 7343997 , https://www.researchgate.net/publication/286459105.

[18] Manoj Kumar Panjwani, Dr. Ghous Bukshsh Narejo1, 2014, "Effect of humidity on the efficiency of solar cell (photovoltaic)", International Journal of Engineering Research and General Science Volume 2, Issue 4, June-July, ISSN 20912730 .

[19] Abdou Latif Bonkaney1, Saidou Madougou, Rabani Adamou, 2017, "Impact of climatic parameters on the performance of solar photovoltaic (PV) module in Niamey", Smart Grid and Renewable Energy, vol. 8, pp379-393. 